\title{
Multifaceted circuit functions of adult-born neurons [version
}

\section{1; peer review: 4 approved]}

\author{
Cristina V. Dieni1 ${ }^{1}$ Jose Carlos Gonzalez², Linda Overstreet-Wadiche(i)2 \\ ${ }^{1}$ Department of Ophthalmology and Visual Sciences, University of Alabama at Birmingham, Birmingham, AL, 35294, USA \\ ${ }^{2}$ Department of Neurobiology, University of Alabama at Birmingham, Birmingham, AL, 35294, USA
}

V1 First published: 26 Nov 2019, 8(F1000 Faculty Rev):1998

https://doi.org/10.12688/f1000research.20642.1

Latest published: 26 Nov 2019, 8(F1000 Faculty Rev):1998

https://doi.org/10.12688/f1000research.20642.1

\section{Abstract}

The dentate gyrus continually produces new neurons throughout life. Behavioral studies in rodents and network models show that new neurons contribute to normal dentate functions, but there are many unanswered questions about how the relatively small population of new neurons alters network activity. Here we discuss experimental evidence that supports multiple cellular mechanisms by which adultborn neurons contribute to circuit function. Whereas past work focused on the unique intrinsic properties of young neurons, more recent studies also suggest that adult-born neurons alter the excitability of the mature neuronal population via unexpected circuit interactions.

\section{Keywords}

adult neurogenesis, dentate gyrus, circuit, excitability, inhibition, glutamate

\section{Open Peer Review}

Approval Status

1

2

3

4

version 1

26 Nov 2019

Faculty Reviews are review articles written by the prestigious Members of Faculty Opinions. The articles are commissioned and peer reviewed before publication to ensure that the final, published version is comprehensive and accessible. The reviewers who approved the final version are listed with their names and affiliations.

1. Silvia De Marchis, Neuroscience Institute Cavalieri Ottolenghi (NICO), University of Turin, Orbassano, Italy

2. Benjamin R Arenkiel, Baylor College of Medicine, Houston, USA

3. Alejandro F Schinder, Fundación Instituto Leloir, Buenos Aires, Argentina

Mariela Trinchero, Fundación Instituto

Leloir, Buenos Aires, Argentina

4. Helen E. Scharfman, New York University

Langone Health, New York, USA

The Nathan Kline Institute of Psychiatric

Research, New York State Office of Mental 


\section{Health, New York, USA}

Any comments on the article can be found at the end of the article.

Corresponding author: Linda Overstreet-Wadiche (Iwadiche@uab.edu)

Author roles: Dieni CV: Conceptualization, Writing - Original Draft Preparation, Writing - Review \& Editing; Gonzalez JC:

Conceptualization, Writing - Review \& Editing; Overstreet-Wadiche L: Conceptualization, Funding Acquisition, Writing - Original Draft Preparation, Writing - Review \& Editing

Competing interests: No competing interests were disclosed.

Grant information: The authors are supported by University of Alabama (UAB) Faculty Development Grant Program and National Science Foundation (NSF) \#1539034 RII Track-2 Focused EPSCoR Collaborations (FEC): Bridging Cognitive Science and Neuroscience Using Innovative Imaging Technologies (CVD), the American Epilepsy Society (UCG), and National Institutes of Health (NIH) R01NS064025 \& R01NS105438 (LOW).

The funders had no role in study design, data collection and analysis, decision to publish, or preparation of the manuscript.

Copyright: $\odot 2019$ Dieni CV et al. This is an open access article distributed under the terms of the Creative Commons Attribution License, which permits unrestricted use, distribution, and reproduction in any medium, provided the original work is properly cited.

How to cite this article: Dieni CV, Gonzalez JC and Overstreet-Wadiche L. Multifaceted circuit functions of adult-born neurons [version 1; peer review: 4 approved] F1000Research 2019, 8(F1000 Faculty Rev):1998 https://doi.org/10.12688/f1000research.20642.1

First published: 26 Nov 2019, 8(F1000 Faculty Rev):1998 https://doi.org/10.12688/f1000research.20642.1 


\section{Introduction}

The dentate gyrus (DG) is viewed as the main entry point for neural activity into the hippocampus, a brain region essential for learning and memory. The principal neurons, the dentate granule cells (GCs), are innervated by neurons of the entorhinal cortex that encode information about objects, spatial location, and details of the environment ${ }^{1-3}$. Thus, GCs integrate sensory and spatial information to help generate a neural representation of a context ${ }^{4,5}$. Interestingly, resident neural stem cells produce new GCs throughout adulthood, and these adult-born GCs receive synapses from cortical neurons via the perforant path and form output synapses with downstream neurons to participate in hippocampal network activity. Although the majority of neuroblasts undergo programmed cell death, surviving neurons are permanently incorporated into the DG and acquire properties similar to GCs generated early in development ${ }^{6-8}$. While adultborn GCs may replace a fraction of the developmentally generated population that is lost over time ${ }^{6,9,10}$, their continuous addition accounts for the substantial increase in GC number across the first year of life in rodents ${ }^{11,12}$. How this process contributes to hippocampal learning and memory is an intriguing neurobiological question. Current insight into this question relies on experimentally tractable rodent models, but evidence of DG neurogenesis in healthy humans across the lifespan ${ }^{13,14}$ suggests that it could have implications for human cognition.

The DG has long been associated with the computational function of pattern separation or the transformation of afferent activity such that output patterns have less similarity than input patterns ${ }^{15,16}$. Brain regions involved in associative learning, such as the cerebellum and hippocampus, use circuits that perform pattern separation as a "pre-processing" step to help discriminate input patterns carrying sensory or contextual cues ${ }^{17}$. Sparse population activity, wherein only a small fraction of principal neurons are active at a given time, is thought to be a critical component of pattern separation ${ }^{17}$. In the DG, sparse activity is predicted to allow distinct GC ensembles to encode similar (but not identical) patterns of afferent activity, with a large capacity to transform overlapping patterns in the cortex into non-overlapping patterns in CA $3^{18,19}$. Interestingly, selective manipulations of adult-born GCs are sufficient to alter behavior paradigms thought to rely on DG pattern separation (reviewed in 20). Adult-born neurons likely contribute to DG functions by providing different information-processing capabilities compared to the existing mature population and by modifying the activity of mature GCs via circuit interactions. Here, we will review multiple cellular mechanisms by which adult-born neurons may contribute to DG network activity with a focus on circuit interactions.

\section{Functional maturation of adult-born GCs}

As newly born GCs develop and integrate into the DG (Figure 1a), they exhibit dramatic changes in morphological, intrinsic, and synaptic properties that distinguish them from the larger population of developmentally generated GCs (Figure 1b). Viral and transgenic tools have enabled detailed understanding of these changes in brain slice preparations (reviewed in 20-23). In young adult rodents, mature electrophysiological properties typically develop over the course of 6-8 weeks, but there is variability in the rate of maturation depending on the age and species of the animal, housing conditions, and other factors ${ }^{24-26}$. Fully developed "mature" GCs share similar properties regardless of their birthdate and arise from a common progenitor population, consistent with the idea that adult neurogenesis represents a continuous extension of early development ${ }^{7,27}$.

Early studies converged on the idea that adult-born GCs transiently exhibit unique properties that provide novel informationprocessing capabilities to the mature circuit. For example, a high propensity for synaptic plasticity between 4 and 6 weeks after cell birth coupled with high intrinsic excitability affords an attractive explanation for the disproportionate contribution of a small population of young GCs within a sparsely active network $^{28-30}$. Preferential recruitment by afferent stimulation suggests young GCs could act as integrators rather than discriminators of afferent activity patterns, raising the paradox that the addition of excitable young GCs could reduce rather than enhance pattern separation ${ }^{31,32}$. Thus, alternative computational functions for new neurons have also been proposed, including time encoding and memory resolution ${ }^{32,33}$. On the other hand, adult-born GCs might contribute to DG pattern separation primarily by modulating the excitability of the sparsely active mature GC population ${ }^{34-36}$.

Subsequent studies of the intrinsic properties of adult-born GCs continue to reveal how their shifting complement of ion channels and receptors can result in distinct informationprocessing capabilities compared to mature $\mathrm{GCs}^{37-45}$. One emerging idea is that despite the robust changes in various intrinsic and synaptic parameters during GC maturation (Figure 1b), the net effect is a similar sparse afferent activation of all GC cohorts (reviewed in 23). For example, the high intrinsic excitability of young GCs is balanced by low innervation from cortical axons in a manner that potentially promotes sparse recruitment and discrimination of patterns due to limited sampling of input space ${ }^{42,44}$. In vivo analysis in behaving rodents combined with knowledge of circuit connectivity and activity patterns of afferent populations will be important to understand precisely how adult-born GCs are recruited during various behavioral states ${ }^{46-49}$. Yet distinct cell-autonomous properties may not fully explain the role of adult neurogenesis in DG circuit function, since developmentally generated GCs presumably mediate the majority of GC activity ${ }^{18,47}$. Rather, recent work has focused on understanding how adult-born GCs modify the activity of the pre-existing GC population via circuit interactions.

\section{Controlling mature GC excitability by feedback inhibition}

Some of the first evidence that adult-born GCs alter the excitability of mature GCs came from voltage-sensitive dye imaging of hippocampal slices from mice with enhanced or ablated neurogenesis ${ }^{50}$. In light of the high intrinsic excitability of young GCs, it was unexpected that the amplitude and spread of afferent-driven depolarization across the DG was reduced when neurogenesis was enhanced. Conversely, depolarization increased when neurogenesis was suppressed. The inverse relationship between the number of new GCs and excitability of the DG could result from adult-born GCs recruiting local 


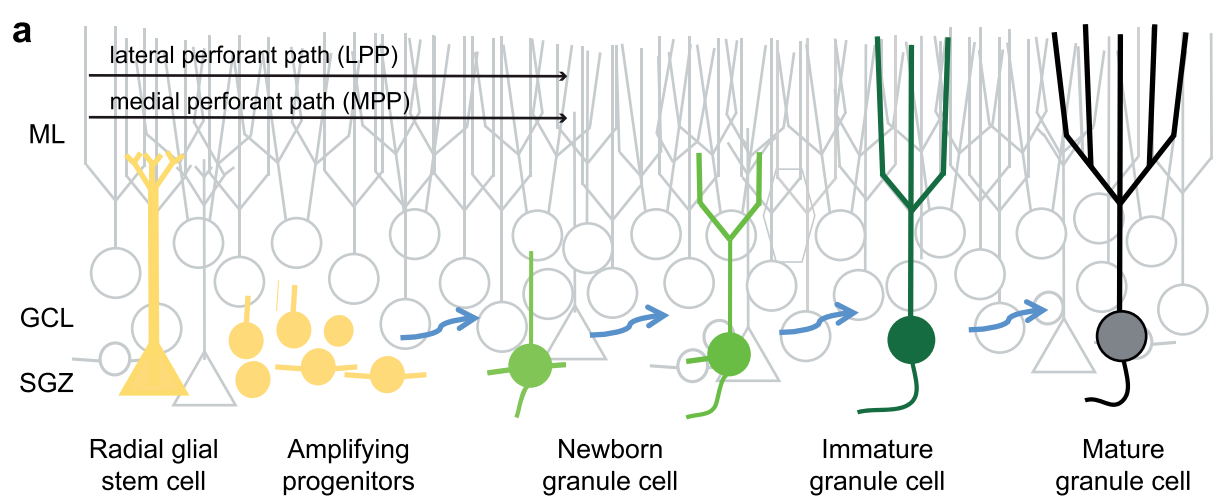

b

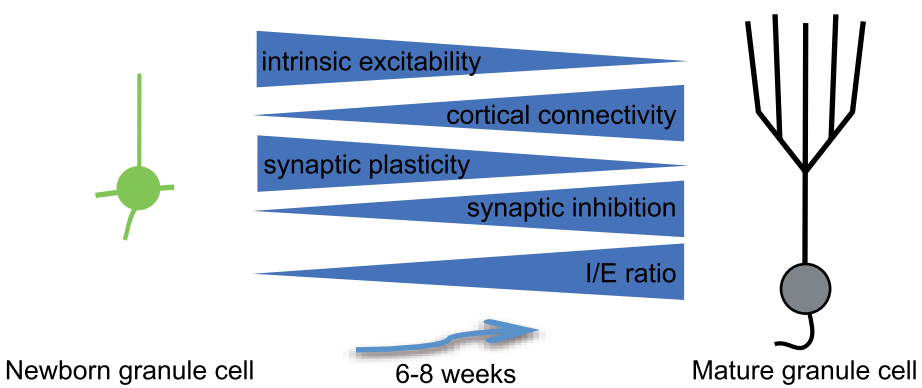

Figure 1. Functional maturation of adult-born granule cells. a. Illustration of the morphological maturation and integration of adult-born granule cells (GCs) (green cells) in the dentate gyrus. Progressive stages of integration are indicated by blue arrows. Yellow cells represent radial glial stem cells and proliferating progenitors. Developmentally generated GCs are gray and the molecular layer (ML), GC layer (GCL), and subgranular zone (SGZ) are indicated. GC dendrites extend through the ML and axons (truncated) project to CA3. b. Summary of the physiological changes that accompany morphological maturation of GCs. Full maturation typically requires 6 to 8 weeks in young adult mice. Blue arrows indicate direction of change, with intrinsic excitability and plasticity decreasing with maturation but synaptic connectivity from the cortex and synaptic inhibition increasing with maturation. The changes in adult-born GC intrinsic and synaptic properties during maturation are reviewed in 20-23.

gamma-aminobutyric acid (GABA)ergic interneurons that inhibit mature GCs, a circuit motif called feedback inhibition. Consistent with this idea, reducing neurogenesis with focal X-irradiation generated bursts of GC activity in vivo ${ }^{35}$ and hypersensitivity to a chemoconvulsant ${ }^{51,52}$. While these studies assayed excitability across the population of GCs, subsequent work acutely silencing young GCs in vivo and ex vivo using designer receptors exclusively activated by designer drugs (DREADDs) also revealed enhanced excitability of individual mature GCs consistent with feedback inhibition ${ }^{53}$.

In fact, GCs are expected to recruit interneurons in the hilus to generate feedback inhibition that contributes to sparse DG activity $^{54-56}$ (Figure 2a). Functional connectivity motifs for lateral inhibition, in which a GC innervates a GABAergic interneuron that innervates neighboring GCs but not themselves, are more abundant in the DG compared to other cortical regions ${ }^{57}$. But whether young GCs exert a more powerful form of feedback inhibition compared to mature GCs, providing a unique contribution to sparse activity, was unclear. To address this question, Temprana and colleagues used a rigorous set of experiments to directly compare feedback inhibition from cohorts of GCs of differing ages expressing channelrhodopsin-2 $(\mathrm{ChR} 2)^{58}$. Whereas feedback inhibition generated by 8 -week-old GCs suppressed perforant path-induced spiking, inhibition evoked by the same number of 4-week-old GCs had little effect (Figure 2b). These results show that feedback inhibition produced by adult-born GCs increases with maturation and argues against the idea that 4-week-old GCs make a unique contribution to feedback inhibition. Similarly, other studies report that ablation of neurogenesis reduced dentate field excitatory postsynaptic potentials (fEPSPs) and population spikes in vivo, inconsistent with a prominent role for feedback inhibition in maintaining low excitability of the GC population $^{35,59}$.

\section{Controlling mature GC excitability by glutamate- mediated excitation and inhibition}

The plot thickened as subsequent work proposed that ChR2 activation of adult-born GCs younger than 7 weeks old provides strong inhibitory responses in neighboring $\mathrm{GCs}^{60}$. These contrasting results could reflect a larger population of adult-born GCs that were manipulated or the use of repetitive rather than single stimuli. But, more remarkably, young GCs appeared to release both the inhibitory transmitter GABA and the excitatory transmitter glutamate directly onto mature GCs. Drew and colleagues ${ }^{60}$ showed ChR2 activation of new GCs generated GABA and N-methyl-D-aspartate receptor (NMDAR)-mediated currents in mature GCs even when polysynaptic activity was blocked by $\alpha$-amino-3-hydroxy-5-methyl-4isoxazolepropionic acid receptor (AMPAR) antagonists. Such recurrent connectivity contrasts sharply with the conventional 
view that GCs provide a unidirectional glutamatergic projection, except in pathological conditions like epilepsy ${ }^{61,62}$. Yet the possibility that young GCs release both GABA and glutamate is consistent with a long-standing literature showing a transient dual-neurotransmitter phenotype, although the nature and prevalence of GABAergic signaling from young GCs has been controversial $^{63-65}$.

Even as the efficacy of GABAergic feedback inhibition recruited by young GCs remains debated, a recent study further expands the potential repertoire of adult-born GC circuit functions by focusing on the direct glutamatergic signaling from young GCs to mature GCs (Figure 3a). Luna and colleagues $^{66}$ first showed that silencing adult-born GCs increased mature GC responses evoked by stimulation of the lateral perforant path (LPP), whereas it reduced mature GC responses evoked by stimulation of the medial perforant path (MPP). Since the LPP carries sensory information and the MPP carries spatial information ${ }^{3}$, adult-born GCs might selectively gate different forms of information during the creation of DG contextual representations in mature GCs. This unexpected pathway-specific regulation was attributed to activation of postsynaptic glutamate receptors on mature GCs rather than feedback inhibition. In fact, blocking GABA receptors did not block the responses evoked by new GCs, suggesting that feedback inhibition generated by young GCs is not a major circuit function in this paradigm.

Glutamate activates ionotropic AMPARs and NMDARs to depolarize neurons, but in some neurons, including GCs, glutamate also activates metabotropic glutamate receptors (mGluRs) coupled to potassium channels that cause hyperpolarization ${ }^{67,68}$. Luna and colleagues showed that optogenetic activation of young GCs evoked NMDAR-mediated excitatory postsynaptic potentials (EPSPs) in mature GCs as well as slow inhibitory postsynaptic potentials (IPSPs) driven by mGluRs. Such
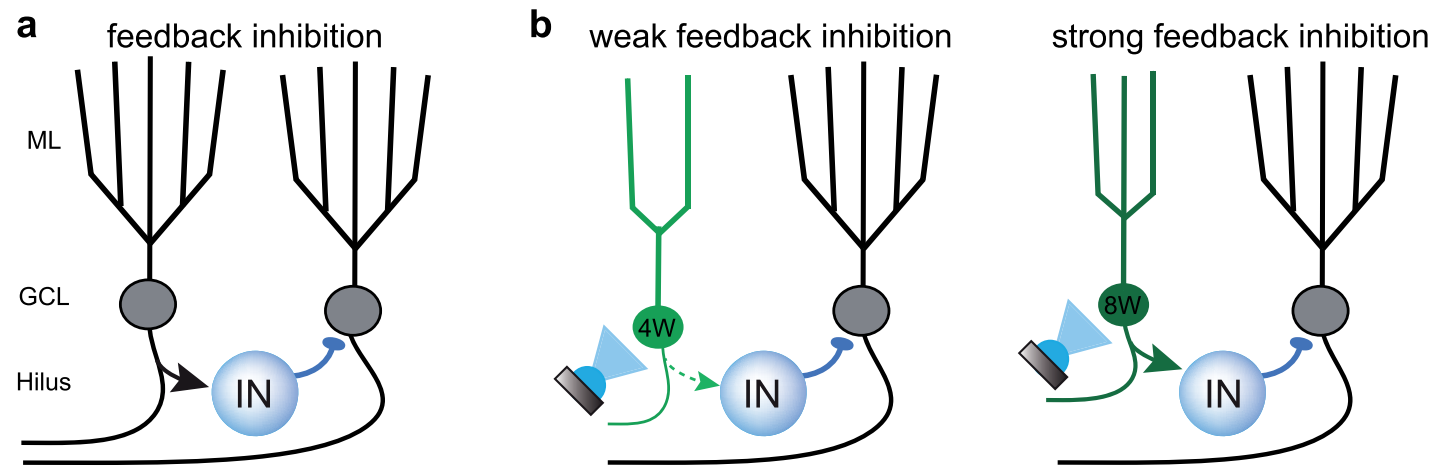

Figure 2. Controlling mature granule cell excitability by feedback inhibition. a. Depiction of feedback inhibition in the dentate gyrus (DG) wherein granule cells (GCs) recruit GABAergic interneurons (IN) that in turn inhibit GCs. Arrows indicate excitatory glutamatergic synapses and circles indicate inhibitory GABAergic synapses. A common feedback motif in the DG is lateral inhibition, where GCs inhibit their neighbors but not themselves ${ }^{57}$. b. Summary of results from Temprana et al. ${ }^{58}$ showing optogenetic activation of 4 -week-old adult-born GCs (4W) generates little feedback inhibition (left) whereas activation of 8-week-old adult-born GCs (8W) generates effective feedback inhibition. The size of the arrow indicates the relative strength of interneuron recruitment. GCL, granule cell layer; ML, molecular layer.

a

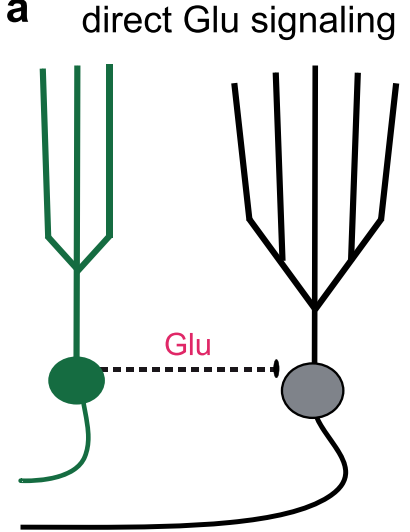

b

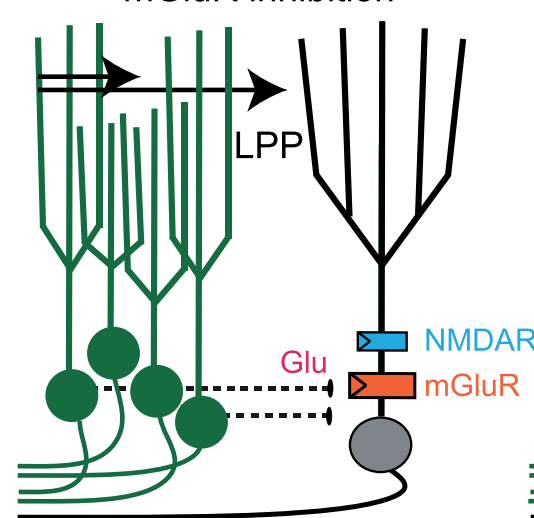

NMDAR depolarization

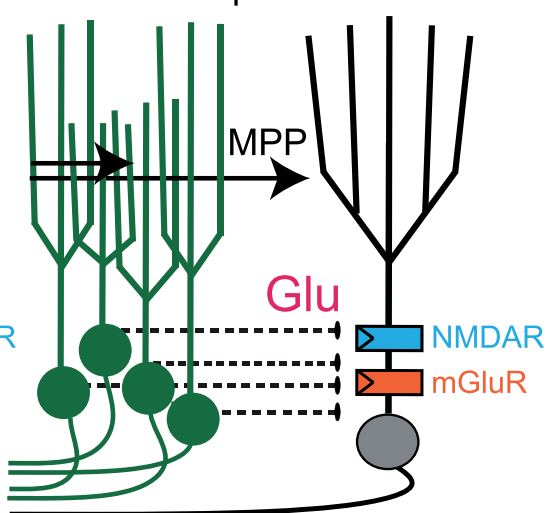

Figure 3. Controlling mature granule cell excitability by glutamate-mediated excitation and inhibition. a. Depiction of young granule cells (GCs) (green) releasing glutamate (Glu) directly onto mature GCs (black). b. Summary of the proposed circuit mechanism from Luna et al. ${ }^{66}$, whereby direct glutamatergic signaling allows pathway-specific modulation of mature GC excitability. Left: stimulation of the lateral perforant path (LPP) recruits a small number of young GCs, leading to low Glu levels sufficient to activate extrasynaptic metabotropic Glu receptors (mGluRs) (orange) that hyperpolarize mature GCs. Right: stimulation of the medial perforant path (MPP) recruits a larger number of young GCs, releasing more Glu that also activates extrasynaptic N-methyl-D-aspartate receptors (NMDARs) (blue) that depolarize mature GCs. 
NMDAR- and mGluR-driven responses are characteristic of spillover signaling, wherein receptors located outside of synapses are activated by glutamate acting at a distance from the release site. Spillover transmission can occur in the absence of anatomically defined synaptic junctions or in addition to conventional point-to-point synaptic transmission ${ }^{68-71}$. The authors suggest that when a small number of young GCs are activated by LPP stimulation, the relatively low level of glutamate spillover favors mGluR-mediated inhibition, whereas a larger population of young GCs activated by MPP stimulation recruit stronger NMDAR-mediated depolarization that overrides mGluR inhibition. Thus, the number of young GCs recruited will affect their circuit function (Figure 3b). In this manner, direct glutamatergic signaling from young GCs is poised to influence the information content of neural representations encoded by mature GCs.

\section{Modifying mature GC excitability by synaptic redistribution}

Whereas Luna et al. ${ }^{66}$ described circuit interactions that enable adult-born GCs to rapidly modify mature GC excitability in response to network activity, neurogenesis also changes synaptic structure and function of existing GCs over a longer time window as young GCs integrate into the circuit. The possibility that newborn GCs compete for synaptic input with existing GCs was implied by evidence that the survival of newborn GCs is competitively regulated by NMDAR activation ${ }^{72}$. Subsequent anatomical analysis showed that immature dendritic spines transiently receive a high proportion of synapses from multiple-synapse boutons that could represent an intermediate structure in the transfer of cortical synapses from old to new $\mathrm{GCs}^{73,74}$ (but see 75 ). Whether the addition of adult-born GCs increases the number of synapses in the circuit or causes redistribution of existing synapses has important implications for understanding neurogenesis-induced plasticity. Indeed, changes in the number of GCs does not necessarily alter the number of input and output synapses. For example, early work showed that the density of middle molecular layer synapses is constant over the first year of postnatal life despite an increase in GC number ${ }^{11,12,76,77}$. In accordance with a redistribution of available presynaptic and postsynaptic elements, ablating GCs enhances the density of GABAergic somatic synapses on remaining $\mathrm{GCs}^{78}$ and increasing the number of new GCs does not appear to alter the density of spines and synapses in the molecular layer ${ }^{79}$. Recent support for the hypothesis that new GCs integrate into the circuit by competing for pre-existing synapses was provided by complementary studies showing that reducing the spine density of mature GCs enhanced the integration of new $\mathrm{GCs}^{80}$ and that manipulating the number of newborn GCs inversely regulated synaptic connectivity of mature $\mathrm{GCs}^{81}$. Thus, synaptic competition and subsequent redistribution of cortical connectivity may provide an additional mechanism for neurogenesis to contribute to sparsity and decorrelation of mature GC activity ${ }^{20}$.

\section{Conclusions}

The possibility that young GCs influence mature GC excitability by direct glutamatergic excitation and inhibition suggests an unexpectedly complex regulation layered upon additional secondary influences including feedback inhibition and synaptic competition. On the surface, it is difficult to envision the purpose of simultaneous direct excitation and inhibition. Luna et al. ${ }^{66}$ propose that dual signaling allows young GCs to differentially regulate mature GC excitability depending on the strength of LPP versus MPP activity that differs between behavioral states and in the superior and inferior blade. Another possibility is that direct excitation/inhibition exerts local effects on neighboring GCs, whereas feedback influences GCs over a larger spatial domain as dictated by the extensive axonal arbors of GABAergic interneurons. Untangling the consequences of these multifaceted circuit interactions on hippocampal encoding and behavior will be an interesting challenge.

Many questions also remain about the mechanisms of these interactions at the cellular and synaptic level. For example, how is glutamate released from young GCs in a manner that generates receptor activation reminiscent of spillover signaling and where does this signaling occur? What is the efficiency of this novel signaling mechanism in controlling mature GC spiking, especially considering the stimulation of a single or small number of young GCs is insufficient to engage these interactions? How does the MPP recruit a larger population of young GCs than the LPP in light of evidence that the LPP preferentially innervates young $\mathrm{GCs}^{82}$ ? Finally, what is the temporal relationship and relative efficacy of direct glutamatergic signaling in comparison with feedback inhibition and synaptic competition at each stage of new GC maturation? While the existing evidence indicates that the integration of new GCs has complex consequences for the local circuit, there is still a long way to go to understand how a few cells affect the many. The multi-layered complexity of the circuit interactions, in combination with activity-dependent regulation of adult neurogenesis, implies that continual neurogenesis provides extraordinary flexibility for adaptation to environmental changes and cognitive demands. Further exploring the cellular mechanisms by which adult-born GCs modify DG excitability and downstream hippocampal activity, along with cell-type-specific manipulations in behaving rodents to test their influence on behavior (reviewed in 83), will be important to decipher the full contribution of neurogenesis to memory encoding and retrieval.

\section{Abbreviations}

AMPAR, $\quad \alpha$-amino-3-hydroxy-5-methyl-4-isoxazolepropionic acid receptor; ChR2, channelrhodopsin-2; DG, dentate gyrus; EPSP, excitatory postsynaptic potential; GABA, gammaaminobutyric acid; GC, granule cell; IPSP, inhibitory postsynaptic potential; LPP, lateral perforant path; mGluR, metabotropic glutamate receptor; MPP, medial perforant path; NMDAR, $\mathrm{N}$-methyl-D-aspartate receptor.

\section{Acknowledgements}

The authors thank Dr. Jada Vaden (University of Alabama at Birmingham) and William Kennedy (University of Alabama at Birmingham) for helpful comments and discussions. 
1. F Kitamura T, Sun C, Martin J, et al.: Entorhinal Cortical Ocean Cells Encode Specific Contexts and Drive Context-Specific Fear Memory. Neuron. 2015 87(6): 1317-31.

PubMed Abstract | Publisher Full Text | Free Full Text | F1000 Recommendation

2. F Diehl GW, Hon OJ, Leutgeb S, et al:: Grid and Nongrid Cells in Medial Entorhinal Cortex Represent Spatial Location and Environmental Features with Complementary Coding Schemes. Neuron. 2017; 94(1): 83-92.e6. PubMed Abstract | Publisher Full Text | Free Full Text | F1000 Recommendation

3. Sugar J, Moser MB: Episodic memory: Neuronal codes for what, where, and when. Hippocampus. 2019: 29(12): 1190-1205.

PubMed Abstract | Publisher Full Text

4. Treves A, Tashiro A, Witter MP, et al.: What is the mammalian dentate gyrus good for? Neuroscience. 2008; 154(4): 1155-72. PubMed Abstract | Publisher Full Text

5. F Liu X, Ramirez S, Pang PT, et al:: Optogenetic stimulation of a hippocampal engram activates fear memory recall. Nature. 2012; 484(7394): 381-5. PubMed Abstract | Publisher Full Text | Free Full Text | F1000 Recommendation

6. Dayer AG, Ford AA, Cleaver KM, et al:: Short-term and long-term survival of new neurons in the rat dentate gyrus. J Comp Neurol. 2003; 460(4): 563-72. PubMed Abstract | Publisher Full Text

7. Laplagne DA, Espósito MS, Piatti VC, et al:: Functional convergence of neurons generated in the developing and adult hippocampus. PLOS Biol. 2006; 4(12): e409.

PubMed Abstract | Publisher Full Text | Free Full Text

8. $\quad \mathrm{F}$ Sierra A, Encinas JM, Deudero JJ, et al:: Microglia shape adult hippocampal neurogenesis through apoptosis-coupled phagocytosis. Cell Stem Cell. 2010; 7(4): 483-95.

PubMed Abstract | Publisher Full Text | Free Full Text | F1000 Recommendation

9. $\quad \mathrm{F}$ Cahill SP, Yu RQ, Green D, et al:: Early survival and delayed death of developmentally-born dentate gyrus neurons. Hippocampus. 2017; 27(11): 1155-67.

PubMed Abstract | Publisher Full Text | F1000 Recommendation

10. Ciric T, Cahill SP, Snyder JS: Dentate gyrus neurons that are born at the peak of development, but not before or after, die in adulthood. Brain Behav. 2019; 9(10): e01435.

PubMed Abstract | Publisher Full Text | Free Full Text

11. Bayer SA, Yackel JW, Puri PS: Neurons in the rat dentate gyrus granular layer substantially increase during juvenile and adult life. Science. 1982; 216(4548): 890-2.

PubMed Abstract | Publisher Full Text

12. F Imayoshi I, Sakamoto M, Ohtsuka T, et al:: Roles of continuous neurogenesis in the structural and functional integrity of the adult forebrain. Nat Neurosci. 2008; 11(10): 1153-61.

PubMed Abstract | Publisher Full Text | F1000 Recommendation

13. F Moreno-Jiménez EP, Flor-García M, Terreros-Roncal J, et al:: Adult hippocampal neurogenesis is abundant in neurologically healthy subjects and drops sharply in patients with Alzheimer's disease. Nat Med. 2019; 25(4): 554-60. PubMed Abstract | Publisher Full Text | F1000 Recommendation

14. F Snyder JS: Recalibrating the Relevance of Adult Neurogenesis. Trends Neurosci. 2019; 42(3): 164-78.

PubMed Abstract | Publisher Full Text | F1000 Recommendation

15. O'Reilly RC, McClelland JL: Hippocampal conjunctive encoding, storage, and recall: avoiding a trade-off. Hippocampus. 1994; 4(6): 661-82. PubMed Abstract | Publisher Full Text

16. $\mathrm{F}$ Madar $\mathrm{AD}$, Ewell LA, Jones MV: Pattern separation of spiketrains in hippocampal neurons. Sci Rep. 2019; 9(1): 5282

PubMed Abstract | Publisher Full Text | Free Full Text | F1000 Recommendation

17. F Cayco-Gajic NA, Silver RA: Re-evaluating Circuit Mechanisms Underlying Pattern Separation. Neuron. 2019; 101(4): 584-602.

PubMed Abstract | Publisher Full Text | F1000 Recommendation

18. Deng W, Mayford M, Gage FH: Selection of distinct populations of dentate granule cells in response to inputs as a mechanism for pattern separation in mice. eLife. 2013; 2: e00312.

PubMed Abstract | Publisher Full Text | Free Full Text

19. Santoro A: Reassessing pattern separation in the dentate gyrus. Front Behav Neurosci. 2013; 7: 96.

PubMed Abstract | Publisher Full Text | Free Full Text

20. F Miller SM, Sahay A: Functions of adult-born neurons in hippocampal memory interference and indexing. Nat Neurosci. 2019; 22(10): 1565-75. PubMed Abstract | Publisher Full Text | F1000 Recommendation

21. Enikolopov G, Overstreet-Wadiche L, Ge S: Viral and transgenic reporters and genetic analysis of adult neurogenesis. Cold Spring Harb Perspect Biol. 2015; 7(8): a018804.

PubMed Abstract | Publisher Full Text | Free Full Text

22. Piatti VC, Espósito MS, Schinder AF: The timing of neuronal development in adult hippocampal neurogenesis. Neuroscientist. 2006; 12(6): 463-8. PubMed Abstract | Publisher Full Text

23. $\mathrm{F}$ Lodge M, Bischofberger J: Synaptic properties of newly generated granule cells support sparse coding in the adult hippocampus. Behav Brain Res. 2019 372: 112036 .

PubMed Abstract | Publisher Full Text | F1000 Recommendation

24. Overstreet-Wadiche LS, Bensen AL, Westbrook GL: Delayed development of adult-generated granule cells in dentate gyrus. J Neurosci. 2006; 26(8): 2326-34. PubMed Abstract | Publisher Full Text | Free Full Text

25. Overstreet-Wadiche LS, Bromberg DA, Bensen AL, et al.: Seizures accelerate functional integration of adult-generated granule cells. J Neurosci. 2006; 26(15): 4095-103

PubMed Abstract | Publisher Full Text | Free Full Text

26. F Piatti VC, Davies-Sala MG, Espósito MS, et al:: The timing for neuronal maturation in the adult hippocampus is modulated by local network activity. $J$ Neurosci. 2011; 31(21): 7715-28.

PubMed Abstract | Publisher Full Text | Free Full Text | F1000 Recommendation

27. F Berg DA, Su Y, Jimenez-Cyrus D, et al:: A Common Embryonic Origin of Stem Cells Drives Developmental and Adult Neurogenesis. Cell. 2019; 177(3): 654-668.e15.

PubMed Abstract | Publisher Full Text | Free Full Text | F1000 Recommendation

28. F Schmidt-Hieber C, Jonas P, Bischofberger J: Enhanced synaptic plasticity in newly generated granule cells of the adult hippocampus. Nature. 2004 429(6988): 184-7.

PubMed Abstract | Publisher Full Text | F1000 Recommendation

29. F Ge S, Yang CH, Hsu KS, et al:: A critical period for enhanced synaptic plasticity in newly generated neurons of the adult brain. Neuron. 2007; 54(4): plasticity

PubMed Abstract | Publisher Full Text | Free Full Text | F1000 Recommendation

30. $\quad F$ Marín-Burgin A, Mongiat LA, Pardi MB, et al.: Unique processing during a period of high excitation/inhibition balance in adult-born neurons. Science. 2012; 335(6073): 1238-42.

PubMed Abstract | Publisher Full Text | Free Full Text | F1000 Recommendation

31. Toni N, Schinder AF: Maturation and Functional Integration of New Granule Cells into the Adult Hippocampus. Cold Spring Harb Perspect Biol. 2015; 8(1) a018903.

PubMed Abstract | Publisher Full Text | Free Full Text

32. F Aimone JB, Wiles J, Gage FH: Computational influence of adult neurogenesis on memory encoding. Neuron. 2009; 61(2): 187-202.

PubMed Abstract | Publisher Full Text | Free Full Text | F1000 Recommendation

33. Aimone JB, Deng W, Gage FH: Resolving new memories: a critical look the dentate gyrus, adult neurogenesis, and pattern separation. Neuron. 2011; 70(4): 589-96.

PubMed Abstract | Publisher Full Text | Free Full Text

34. F Sahay A, Wilson DA, Hen R: Pattern separation: a common function for new neurons in hippocampus and olfactory bulb. Neuron. 2011; 70(4): 582-8. PubMed Abstract | Publisher Full Text | Free Full Text | F1000 Recommendation

35. Lacefield CO, Itskov V, Reardon T, et al.: Effects of adult-generated granule cells on coordinated network activity in the dentate gyrus. Hippocampus. 2012; 22(1): 106-16.

PubMed Abstract | Publisher Full Text | Free Full Text

36. Piatti VC, Ewell LA, Leutgeb JK: Neurogenesis in the dentate gyrus: carrying the message or dictating the tone. Front Neurosci. 2013; 7: 50

PubMed Abstract | Publisher Full Text | Free Full Text

37. Mongiat LA, Espósito MS, Lombardi G, et al:: Reliable activation of immature neurons in the adult hippocampus. PLoS One. 2009; 4(4): e5320. PubMed Abstract | Publisher Full Text | Free Full Text

38. Li Y, Aimone JB, Xu X, et al:: Development of GABAergic inputs controls the contribution of maturing neurons to the adult hippocampal network. Proc Natl Acad Sci U S A. 2012; 109(11): 4290-5.

PubMed Abstract | Publisher Full Text | Free Full Text

39. Dieni CV, Nietz AK, Panichi R, et al.: Distinct determinants of sparse activation during granule cell maturation. J Neurosci. 2013; 33(49): 19131-42. PubMed Abstract | Publisher Full Text | Free Full Text

40. Brunner J, Neubrandt M, Van-Weert S, et al.: Adult-born granule cells mature through two functionally distinct states. eLife. 2014; 3: e03104. PubMed Abstract | Publisher Full Text | Free Full Text

41. Pardi MB, Ogando MB, Schinder AF, et al:: Differential inhibition onto developing and mature granule cells generates high-frequency filters with variable gain. eLife. 2015; 4: e08764.

PubMed Abstract | Publisher Full Text | Free Full Text

42. Dieni CV, Panichi R, Aimone JB, et al.: Low excitatory innervation balances high intrinsic excitability of immature dentate neurons. Nat Commun. 2016; 7: 11313. PubMed Abstract | Publisher Full Text | Free Full Text

43. Heigele S, Sultan S, Toni N, et al.: Bidirectional GABAergic control of action potential firing in newborn hippocampal granule cells. Nat Neurosci. 2016; 
19(2): 263-70

PubMed Abstract | Publisher Full Text

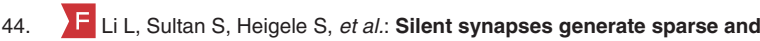
orthogonal action potential firing in adult-born hippocampal granule cells. eLife. 2017; 6: pii: e23612.

PubMed Abstract | Publisher Full Text | Free Full Text | F1000 Recommendation

45. Gonzalez JC, Epps SA, Markwardt SJ, et al.: Constitutive and Synaptic Activation of GIRK Channels Differentiates Mature and Newborn Dentate Granule Cells. J Neurosci. 2018; 38(29): 6513-26. PubMed Abstract | Publisher Full Text | Free Full Text

46. Diamantaki M, Frey $M$, Berens $P$, et al.: Sparse activity of identified dentate granule cells during spatial exploration. eLife. 2016; 5: pii: e20252. PubMed Abstract | Publisher Full Text | Free Full Text

47. Danielson NB, Kaifosh P, Zaremba JD, et al:: Distinct Contribution of Adult-Born Hippocampal Granule Cells to Context Encoding. Neuron. 2016; 90(1): 101-12. PubMed Abstract | Publisher Full Text | Free Full Text

48. F GoodSmith D, Chen X, Wang C, et al:: Spatial Representations of Granule Cells and Mossy Cells of the Dentate Gyrus. Neuron. 2017; 93(3): 677-690.e5. PubMed Abstract | Publisher Full Text | Free Full Text | F1000 Recommendation

49. Senzai Y, Buzsáki G: Physiological Properties and Behavioral Correlates of Hippocampal Granule Cells and Mossy Cells. Neuron. 2017; 93(3): 691-704.e5. PubMed Abstract | Publisher Full Text | Free Full Text

50. F Ikrar T, Guo N, He K, et al.: Adult neurogenesis modifies excitability of the dentate gyrus. Front Neural Circuits. 2013; 7: 204.

PubMed Abstract | Publisher Full Text | Free Full Text | F1000 Recommendation

51. lyengar SS, LaFrancois JJ, Friedman D, et al:: Suppression of adult neurogenesis increases the acute effects of kainic acid. Exp Neurol. 2015; 264: 135-49. PubMed Abstract | Publisher Full Text | Free Full Text

52. Jain S, LaFrancois $\mathrm{JJ}$, Botterill JJ, et al:: Adult neurogenesis in the mouse dentate gyrus protects the hippocampus from neuronal injury following severe seizures. Hippocampus. 2019; 29(8): 683-709. PubMed Abstract | Publisher Full Text | Free Full Text

53. F Anacker C, Luna VM, Stevens GS, et al:: Hippocampal neurogenesis confers stress resilience by inhibiting the ventral dentate gyrus. Nature. 2018; 559(7712): 98-102

PubMed Abstract | Publisher Full Text | Free Full Text | F1000 Recommendation

54. Sloviter RS: Feedforward and feedback inhibition of hippocampal principal cell activity evoked by perforant path stimulation: GABA-mediated mechanisms that regulate excitability in vivo. Hippocampus. 1991; 1(1): 31-40. PubMed Abstract | Publisher Full Text

55. Ewell LA, Jones MV: Frequency-tuned distribution of inhibition in the dentate gyrus. J Neurosci. 2010; 30(38): 12597-607.

PubMed Abstract | Publisher Full Text | Free Full Text

56. Jinde $\mathrm{S}$, Zsiros V, Jiang Z, et al.: Hilar mossy cell degeneration causes transient dentate granule cell hyperexcitability and impaired pattern separation. Neuron. 2012; 76(6): 1189-200

PubMed Abstract | Publisher Full Text | Free Full Text

57. F Espinoza C, Guzman SJ, Zhang X, et al:: Parvalbumin+ interneurons obey unique connectivity rules and establish a powerful lateral-inhibition microcircuit in dentate gyrus. Nat Commun. 2018; 9(1): 4605 PubMed Abstract | Publisher Full Text | Free Full Text | F1000 Recommendation

58. F Temprana SG, Mongiat LA, Yang SM, et al:: Delayed coupling to feedback inhibition during a critical period for the integration of adult-born granule cells. Neuron. 2015; 85(1): 116-30.

PubMed Abstract | Publisher Full Text | Free Full Text | F1000 Recommendation

59. Park EH, Burghardt NS, Dvorak D, et al.: Experience-Dependent Regulation of Dentate Gyrus Excitability by Adult-Born Granule Cells. J Neurosci. 2015 35(33): 11656-66.

PubMed Abstract | Publisher Full Text | Free Full Text

60. Drew LJ, Kheirbek MA, Luna VM, et al:: Activation of local inhibitory circuits in the dentate gyrus by adult-born neurons. Hippocampus. 2016; 26(6): 763-78. PubMed Abstract | Publisher Full Text | Free Full Text

61. Scharfman HE, Sollas AL, Berger RE, et al:: Electrophysiological evidence of monosynaptic excitatory transmission between granule cells after seizureinduced mossy fiber sprouting. J Neurophysiol. 2003; 90(4): 2536-47. PubMed Abstract | Publisher Full Text

62. Hendricks WD, Chen Y, Bensen AL, et al:: Short-Term Depression of Sprouted Mossy Fiber Synapses from Adult-Born Granule Cells. J Neurosci. 2017; 37(23): 5722-35.

PubMed Abstract | Publisher Full Text | Free Full Text

63. Cabezas C, Irinopoulou T, Gauvain G, et al:: Presynaptic but not postsynaptic GABA signaling at unitary mossy fiber synapses. J Neurosci. 2012; 32(34): GABA signal

PubMed Abstract | Publisher Full Text | Free Full Text
64. Cabezas C, Irinopoulou T, Cauli B, et al.: Molecular and functional characterization of GAD67-expressing, newborn granule cells in mouse dentate gyrus. Front Neural Circuits. 2013; 7: 60

PubMed Abstract | Publisher Full Text | Free Full Text

65. Uchigashima M, Fukaya M, Watanabe M, et al.: Evidence against GABA release from glutamatergic mossy fiber terminals in the developing hippocampus. J Neurosci. 2007; 27(30): 8088-100.

PubMed Abstract | Publisher Full Text | Free Full Text

66. F Luna VM, Anacker C, Burghardt NS, et al.: Adult-born hippocampal neurons bidirectionally modulate entorhinal inputs into the dentate gyrus. Science. 2019; 364(6440): 578-83.

PubMed Abstract | Publisher Full Text | Free Full Text | F1000 Recommendation

67. Brunner J, Ster J, Van-Weert S, et al:: Selective silencing of individual dendritic branches by an mGlu2-activated potassium conductance in dentate gyrus granule cells. J Neurosci. 2013; 33(17): 7285-98. PubMed Abstract | Publisher Full Text | Free Full Text

68. Nietz AK, Vaden JH, Coddington LT, et al:: Non-synaptic signaling from cerebellar climbing fibers modulates Golgi cell activity. eLife. 2017; 6: pii: e29215. PubMed Abstract | Publisher Full Text | Free Full Text

69. F Szapiro G, Barbour B: Multiple climbing fibers signal to molecular layer interneurons exclusively via glutamate spillover. Nat Neurosci. 2007; 10(6): 735-42.

PubMed Abstract | Publisher Full Text | F1000 Recommendation

70. Kullmann DM: Spillover and synaptic cross talk mediated by glutamate and GABA in the mammalian brain. Prog Brain Res. 2000; 125: 339-51. PubMed Abstract | Publisher Full Text

71. Coddington LT, Nietz AK, Wadiche Jl: The contribution of extrasynaptic signaling to cerebellar information processing. Cerebellum. 2014; 13(4): 513-20. PubMed Abstract | Publisher Full Text | Free Full Text

72. $\mathrm{F}$ Tashiro A, Sandler VM, Toni N, et al:: NMDA-receptor-mediated, cell-specific integration of new neurons in adult dentate gyrus. Nature. 2006; 442(7105): 929-33.

PubMed Abstract | Publisher Full Text | F1000 Recommendation

73. $\mathrm{F}$ Toni N, Teng EM, Bushong EA, et al:: Synapse formation on neurons born in the adult hippocampus. Nat Neurosci. 2007; 10(6): 727-34 PubMed Abstract | Publisher Full Text | F1000 Recommendation

74. Toni N, Sultan S: Synapse formation on adult-born hippocampal neurons. Eur J Neurosci. 2011; 33(6): 1062-8. PubMed Abstract | Publisher Full Text

75. Bosch C, Martínez A, Masachs N, et al.: FIB/SEM technology and highthroughput 3D reconstruction of dendritic spines and synapses in GFPlabeled adult-generated neurons. Front Neuroanat. 2015; 9: 60. PubMed Abstract | Publisher Full Text | Free Full Text

76. McWilliams JR, Lynch G: Synaptic density and axonal sprouting in rat hippocampus: Stability in adulthood and decline in late adulthood. Brain Res. 1984; 294(1): 152-6.

PubMed Abstract | Publisher Full Text

77. Tigges J, Herndon JG, Rosene DL: Preservation into old age of synaptic number and size in the supragranular layer of the dentate gyrus in rhesus monkeys. Acta Anat (Basel). 1996; 157(1): 63-72. PubMed Abstract | Publisher Full Text

78. Lee KS, Gerbrandt L, Lynch G: Axo-somatic synapses in the normal and Xirradiated dendate gyrus: Factors affecting the density of afferent innervation. Brain Res. 1982; 249(1): 51-6. PubMed Abstract | Publisher Full Text

79. Kim WR, Park OH, Choi S, et al.: The maintenance of specific aspects of neuronal function and behavior is dependent on programmed cell death of adult-generated neurons in the dentate gyrus. Eur J Neurosci. 2009; 29(7): 1408-21.

PubMed Abstract | Publisher Full Text | Free Full Text

80. McAvoy KM, Scobie KN, Berger S, et al.: Modulating Neuronal Competition Dynamics in the Dentate Gyrus to Rejuvenate Aging Memory Circuits. Neuron. 2016; 91(6): 1356-73.

PubMed Abstract | Publisher Full Text | Free Full Text

81. F Adlaf EW, Vaden RJ, Niver AJ, et al:: Adult-born neurons modify excitatory synaptic transmission to existing neurons. eLife. 2017; 6: pii: e19886. PubMed Abstract | Publisher Full Text | Free Full Text | F1000 Recommendation

82. Woods NI, Vaaga CE, Chatzi C, et al:: Preferential Targeting of Lateral Entorhina Inputs onto Newly Integrated Granule Cells. J Neurosci. 2018; 38(26): 5843-53. PubMed Abstract | Publisher Full Text | Free Full Text

83. Tuncdemir SN, Lacefield CO, Hen R: Contributions of adult neurogenesis to dentate gyrus network activity and computations. Behav Brain Res. 2019; 374 112112.

PubMed Abstract | Publisher Full Text | Free Full Text 


\section{Open Peer Review}

\section{Current Peer Review Status:}

\section{Editorial Note on the Review Process}

Faculty Reviews are review articles written by the prestigious Members of Faculty Opinions. The articles are commissioned and peer reviewed before publication to ensure that the final, published version is comprehensive and accessible. The reviewers who approved the final version are listed with their names and affiliations.

\section{The reviewers who approved this article are:}

\section{Version 1}

\section{Helen E. Scharfman}

1 Departments of Child \& Adolescent Psychiatry, Neuroscience \& Physiology, and Psychiatry and the New York University (NYU) Neuroscience Institute, New York University Langone Health, New York, NY, USA

2 Center for Dementia Research, The Nathan Kline Institute of Psychiatric Research, New York State Office of Mental Health, New York, NY, USA

Competing Interests: No competing interests were disclosed.

\section{Alejandro F Schinder} Laboratorio de Plasticidad Neuronal, Fundación Instituto Leloir, Buenos Aires, C1405BWE, Argentina Mariela Trinchero Laboratorio de Plasticidad Neuronal, Fundación Instituto Leloir, Buenos Aires, Argentina Competing Interests: No competing interests were disclosed.

\section{Benjamin R Arenkiel} Program in Developmental Biology, Baylor College of Medicine, Houston, TX, USA

Competing Interests: No competing interests were disclosed.

\section{Silvia De Marchis}

Department of Life Sciences and Systems Biology (DBIOS), Neuroscience Institute Cavalieri Ottolenghi (NICO), University of Turin, Orbassano, Italy

Competing Interests: No competing interests were disclosed. 
The benefits of publishing with F1000Research:

- Your article is published within days, with no editorial bias

- You can publish traditional articles, null/negative results, case reports, data notes and more

- The peer review process is transparent and collaborative

- Your article is indexed in PubMed after passing peer review

- Dedicated customer support at every stage

For pre-submission enquiries, contact research@f1000.com 